\title{
Investigation of tribological characteristics of nickel alloy- based solid-lubricating composites at elevated temperatures under vacuum
}

\author{
Jinming ZHEN ${ }^{1,2}$, Jun CHENG ${ }^{2, *}$, Hui TAN ${ }^{2}$, Qichun SUN ${ }^{2}$, Shengyu ZHU ${ }^{2}$, Jun YANG ${ }^{2, *}$, Weimin LIU ${ }^{2}$ \\ ${ }^{1}$ College of Materials Science and Engineering, Liaocheng University, Liaocheng 252059, China \\ ${ }^{2}$ State Key Laboratory of Solid Lubrication, Lanzhou Institute of Chemical Physics, Chinese Academy of Sciences, Lanzhou \\ 730000, China
}

Received: 03 January 2020 / Revised: 11 March 2020 / Accepted: 15 March 2020

(C) The author(s) 2020.

\begin{abstract}
The development of a high-performance solid-lubricating composite with excellent self-lubricity over a broad temperature range in vacuum is significant to solve the frictional problems of spatial mechanisms. In this study, the vacuum tribological behaviors of nickel-matrix/Ag/(Ca, Ba) $\mathrm{F}_{2} /$ graphite $(0-2 \mathrm{wt} \%)$ composites were studied from 25 to $800{ }^{\circ} \mathrm{C}$. The results show that the synergistic effects of solid lubricants can significantly improve the tribological properties of the composites in vacuum, with the graphite content contributing considerably. For $2 \mathrm{wt} \%$ graphite, a low friction coefficient $(0.14-0.25)$ and the lowest wear rate $\left((0.12-4.78) \times 10^{-5} \mathrm{~mm}^{3} \cdot \mathrm{N}^{-1} \cdot \mathrm{m}^{-1}\right)$ were observed in vacuum over the entire testing temperature range. Moreover, the wear mechanisms were clarified via analysis of the chemical composition and morphologies of the sliding surfaces.
\end{abstract}

Keywords: metal matrix composite; graphite; solid lubrication; vacuum; high temperature

\section{Introduction}

With the rapid development of advanced manufacturing systems in the aerospace and automobile industries, high-temperature lubricating materials and technologies are important and have gained much research attention [1-3]. In these systems, various moving components, such as rolling/sliding bearings and gears, operate under extreme conditions, such as high temperatures above $400{ }^{\circ} \mathrm{C}$, high-speed/load, corrosive, and vacuum environments [3-6]. Under such cases, traditional liquid lubricants cannot provide the desired performance because of evaporation, decomposition, coking, and sealing, among other factors [7, 8]. Instead, highperformance solid-lubricating materials show great potential to fulfill the requirements of reducing friction and wear resistance of the moving parts in these harsh environments [9-13]. As reported, NASA and the Air Force Research Laboratory developed two typical and pioneering solid-lubricating materials, respectively [1, 14-17]. The former is a plasma spray (PS) coating comprising a Ni-based alloy matrix, hardener phase, and $\mathrm{Ag}+\mathrm{CaF}_{2} / \mathrm{BaF}_{2}$ eutectic solid lubricants, which have been successfully applied in the aerospace industry. The PS coating facilitated low friction and wear for the first time under broad temperatures (room temperature to $900{ }^{\circ} \mathrm{C}$ ) owing to the synergistic lubricating effect of the $\mathrm{Ag}$ and $\mathrm{CaF}_{2} / \mathrm{BaF}_{2}$ eutectic. The latter is a chameleon coating that reduces the friction and wear automatically by adjusting the surface chemical, structural, and mechanical characteristics when the environment is changed, and the material systems include yttriastabilized zirconia (YSZ)/Au/ $\mathrm{MoS}_{2} /$ diamond-like carbon

* Corresponding authors: Jun CHENG, E-mail: chengjun@licp.cas.cn; Jun YANG, E-mail: jyang@1zb.ac.cn 
(DLC), vanadium nitride ( $\mathrm{VN}) / \mathrm{Ag}$, and so on. Moreover, abundant high-performance metal ( $\mathrm{Ni}, \mathrm{Co}, \mathrm{Fe}$, etc.) [18-21], intermetallic ( $\mathrm{Ni}-\mathrm{Al}, \mathrm{Ti}-\mathrm{Al}, \mathrm{Fe}-\mathrm{Al}$, etc.) [22-24], and ceramic matrix $\left(\mathrm{Si}_{3} \mathrm{~N}_{4}, \mathrm{SiC}, \mathrm{Al}_{2} \mathrm{O}_{3}\right.$, etc.) $[25,26]$ composites with various solid lubricants ( $\mathrm{Ag}, \mathrm{CaF}_{2} / \mathrm{BaF}_{2}$ eutectic, $\mathrm{CaF}_{2}, \mathrm{BaMoO}_{4}, \mathrm{MoS}_{2}$, etc.) have also been designed and present good lubricity over a wide temperature range in air.

It is well known that materials present different lubricating properties under different service environments as their frictional properties are not inherent $[27,28]$. Particularly in space, the service conditions for satellites and aircraft include vacuum along with high/low temperatures; thus, the materials and solid-lubricants have distinct tribological behaviors. For instance, adsorbed gas and surface oxidation will not occur in vacuum as opposed to in air, and the lubricants will fail to lower the friction via adsorption and dissociation of atmospheric water [29]. Additionally, at high temperatures, surface oxidation plays a critical role in determining the lubricity and wear resistance of the solid-lubricating composites. Some solid-lubricants form a lubricous glazed layer by tribo-oxidation, like transition metal dichalcogenides and high-temperature alloys, among others [5, 30, 31]. Meanwhile, for soft metal lubricants (e.g., $\mathrm{Ag}, \mathrm{Cu}$, and $\mathrm{Au}$ ), during the sliding process, oxidation will break the lubricating film that forms on the contact surface [32-34]. Therefore, it is essential to study the high-temperature vacuum tribological behaviors of solid-lubricating materials; however, the relevant research remains at a primary stage.

Furthermore, the addition of a strengthening phase into composites is an effective method to enhance their wear resistance properties, and many studies have been conducted to prove this [25, 35, 36]. Among these strengthening phases, graphite has been widely applied due to its low cost, excellent selflubricating performance, and can form carbides in situ during sintering $[32,37]$. In our previous work, a Ni-alloy matrix composite containing $\mathrm{Ag}+\mathrm{CaF}_{2} /$ $\mathrm{BaF}_{2}+$ graphite was designed and exhibits good frictional behavior over a broad temperature range from 25 to $800{ }^{\circ} \mathrm{C}$ in air [32]. In the present study, to further evaluate the potential of this composite under a vacuum environment, its frictional behaviors in a vacuum from 25 to $800{ }^{\circ} \mathrm{C}$ were investigated.

\section{Experimental procedures}

\subsection{Material preparation}

In the present research, three composites with different compositions were fabricated by hot pressing, the compositions are given in Table 1 and a detailed schematic of the material preparation process is shown in Fig. 1. The processing parameters and mechanical properties have been described in another report [32].

\subsection{Tribological tests}

The friction and wear behaviors of the composites were evaluated using a ball-on-disc GHT-1000E vacuum high-temperature tribotester. $\mathrm{A} \mathrm{Si}_{3} \mathrm{~N}_{4}$ ceramic ball with a microhardness of $1,500 \mathrm{HV}$ was used as the counterface. The tribotests were conducted under vacuum and a normal load of $5 \mathrm{~N}$ for a temperature range of $25-800{ }^{\circ} \mathrm{C}$. During the sliding process, the coefficients of friction (COFs) were recorded automatically, while the wear rates were measured using a surface profilometer. To ensure repeatability of the data, the friction tests were repeated three times under the same sliding conditions.

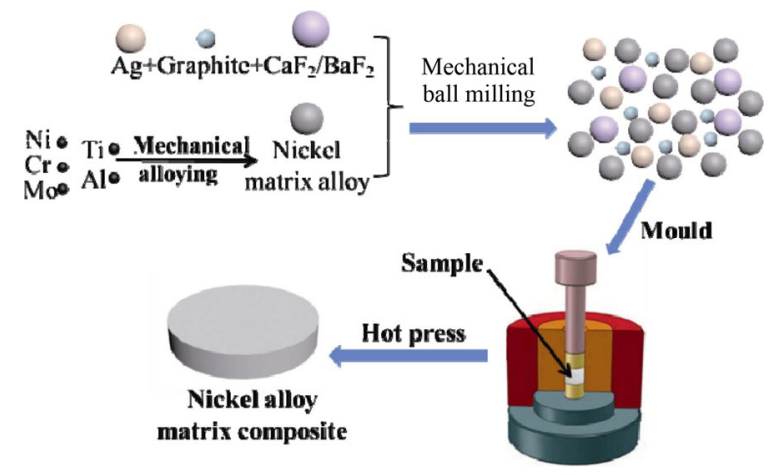

Fig. 1 Schematic diagram of the material preparation process.

Table 1 Composition constitutes of the composites.

\begin{tabular}{ccccc}
\hline Composites & $\begin{array}{c}\mathrm{Ag} \\
(\mathrm{wt} \%)\end{array}$ & $\begin{array}{c}\mathrm{BaF}_{2} / \mathrm{CaF}_{2} \\
\left(\mathrm{wt}^{\mathrm{t}} \%\right)\end{array}$ & $\begin{array}{c}\text { Graphite } \\
(\mathrm{wt} \%)\end{array}$ & Ni-alloy \\
\hline $\mathrm{G} 0$ & 12.5 & 5 & 0 & Balance \\
$\mathrm{G} 0.5$ & 12.5 & 5 & 0.5 & Balance \\
$\mathrm{G} 1$ & 12.5 & 5 & 1 & Balance \\
$\mathrm{G} 2$ & 12.5 & 5 & 2 & Balance \\
\hline
\end{tabular}

Ni-alloy: Ni15Cr12Mo3Ti1 Al (wt\%). 
The Vickers hardness values of the composites at various temperatures $\left(25,200,400,600\right.$, and $800{ }^{\circ} \mathrm{C}$ ) were determined using a high-temperature Vickers hardness tester (HTV-PHS30, Archimedes Industrial Technology Co., Ltd. England) with a load of $9.8 \mathrm{~N}$ and an endurance time of $10 \mathrm{~s}$, the data show the average values of ten measurements each.

Scanning electron microscopy (SEM, JSM- 5600LV), energy-dispersive spectroscopy (EDS), and Raman spectroscopy using a LabRAM HR Evolution (Horiba Jobin Yvon S.A.S., France) were employed to analyze the microstructures and chemical compositions of the worn surfaces for the Ni-alloy matrix composites.

\section{Results and discussion}

\subsection{Microstructures of the composites}

The X-ray diffraction (XRD) patterns of the composites are shown in Fig. 2, the results of which were published in another work [32]. Clearly, the composites comprise $\gamma$ (Ni-matrix), solid lubricants $\left(\mathrm{Ag} /(\mathrm{Ca}, \mathrm{Ba}) \mathrm{F}_{2}\right)$, and carbide (formed in-situ during the hot pressing process) phases. The densities of the composites are listed in Table 2. As the sintering temperatures for the three composites are different, the relative densities of the composites may also differ, and there is no regularity in the density changes of the composites.

The elemental distributions of the Ni-based composites (G0.5) were analyzed to better understand the frictional behavior, as shown in Fig. 3. The

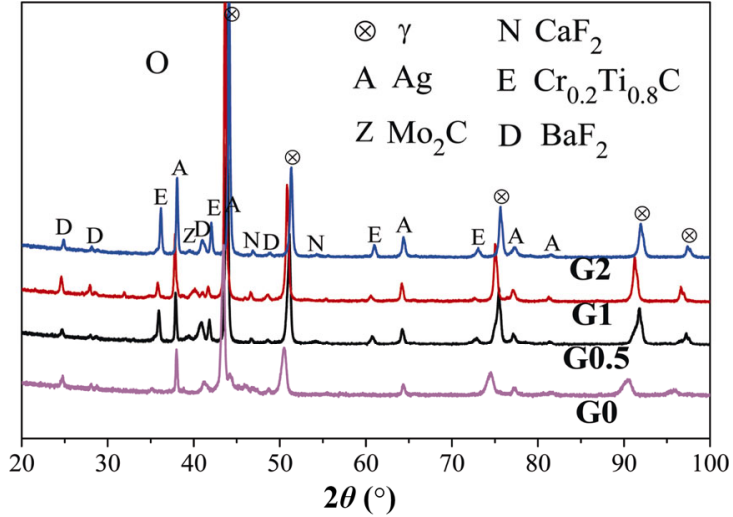

Fig. 2 XRD patterns of the composites.

Table 2 Density of the composites.

\begin{tabular}{cc}
\hline Composites & Density $\left(\mathrm{g} \cdot \mathrm{cm}^{-3}\right)$ \\
\hline G0 & 7.91 \\
G0.5 & 7.85 \\
G1 & 7.33 \\
G2 & 7.92 \\
\hline
\end{tabular}

EDS mapping results show the Ag-rich phase as the white area, fluoride-rich phase as the black area, and the Ni alloy matrix and carbide-rich phase in gray. It should be noted that the distribution of solidlubricants (Ag and fluoride eutectic) is clumped, while the carbide shows continuous stellate distribution.

\subsection{Friction coefficient and wear rate}

The average COF of the Ni-alloy matrix composites from 25 to $800{ }^{\circ} \mathrm{C}$ under the vacuum condition is presented in Fig. 4. Impressively, all four composites exhibit superior lubricity characterized by the COF
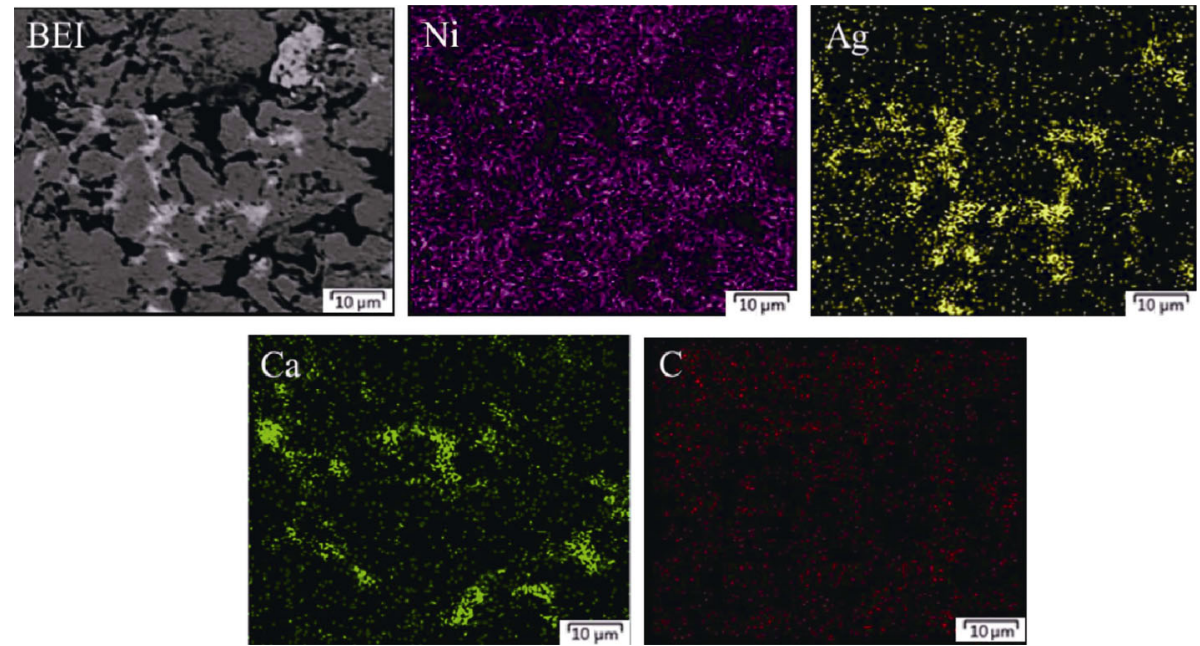

Fig. 3 Back-scattering electron image (BEI) and EDS maps showing the microstructure of composite G0.5. 


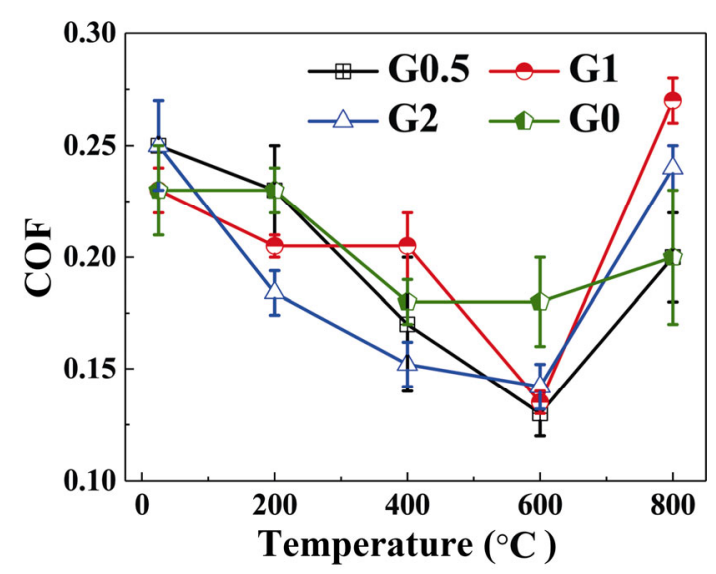

Fig. 4 Friction coefficient of nickel-alloy based composites as a function of temperatures.

of $0.13-0.27$, which is quite lower than that of the composites tested under the air condition, 0.190.62 [33]. The changing trends of the COFs of the four composites with the testing temperatures in vacuum are almost the same as those of the whole. As the temperature was increased from 25 to $600{ }^{\circ} \mathrm{C}$, the COF first continuously decreased and then increased somewhat as the temperature reached $800{ }^{\circ} \mathrm{C}$. Concerning the effect of the graphite content, composite G2 exhibited the lowest COF at 200 and $400{ }^{\circ} \mathrm{C}$, while that of composite G0.5 was the lowest at $800{ }^{\circ} \mathrm{C}$. Moreover, the typical curves of the $\mathrm{COF}$ vs. sliding time for the composites at various temperatures in vacuum are shown in Fig. 5. Composites G1 and G2 exhibit steady COFs from 25 to $200{ }^{\circ} \mathrm{C}$, while the COF of composite G0.5 was steady from 400 to $800{ }^{\circ} \mathrm{C}$, indicating that G0.5 shows superior lubricating performance at moderate to high temperatures. In addition, composite G2 exhibited a lower and steadier COF at 200 and $400{ }^{\circ} \mathrm{C}$ in contrast with composites G0, G0.5, and G1 (Figs. 4 and 5).

The wear rates of the composites for the temperature range of $25-800{ }^{\circ} \mathrm{C}$ in vacuum are shown in Fig. 6 . It is clear that the wear rates are low and in the order of $10^{-6}-10^{-5} \mathrm{~mm}^{3} \cdot \mathrm{N}^{-1} \cdot \mathrm{m}^{-1}$. The samples demonstrate a remarkably lower wear rate of $(0.12-2.3) \times 10^{-5}$ $\mathrm{mm}^{3} \cdot \mathrm{N}^{-1} \cdot \mathrm{m}^{-1}$ in vacuum compared with that in air of $(0.9-46.8) \times 10^{-5} \mathrm{~mm}^{3} \cdot \mathrm{N}^{-1} \cdot \mathrm{m}^{-1}$; however, at $800{ }^{\circ} \mathrm{C}$, the wear rates are approximately $(4.12-10.18) \times 10^{-5}$ $\mathrm{mm}^{3} \cdot \mathrm{N}^{-1} \cdot \mathrm{m}^{-1}$ in vacuum, higher than those in air of approximately $(2.7-4.4) \times 10^{-5} \mathrm{~mm}^{3} \cdot \mathrm{N}^{-1} \cdot \mathrm{m}^{-1}$. Impressively, the wear resistance can be significantly improved by optimizing the graphite content. For composites G0 and G0.5, the wear rates slightly vary over a range of $(1.25-3.02) \times 10^{-5} \mathrm{~mm}^{3} \cdot \mathrm{N}^{-1} \cdot \mathrm{m}^{-1}$ from 25 to $600{ }^{\circ} \mathrm{C}$, while at $800{ }^{\circ} \mathrm{C}$, they increase to the largest value of $7.5 \times 10^{-5} \mathrm{~mm}^{3} \cdot \mathrm{N}^{-1} \cdot \mathrm{m}^{-1}$. For composites G1 and $\mathrm{G} 2$, the wear rates decrease somewhat from 25 to $200{ }^{\circ} \mathrm{C}$, and then increase continuously from 400 to $800{ }^{\circ} \mathrm{C}$. Compared with composites G0.5 and G0, G1 and G2 exhibit better wear resistances for the temperature range of $200-600{ }^{\circ} \mathrm{C}$; at $800{ }^{\circ} \mathrm{C}$, however, composite G0.5 shows a lower wear rate than composites G0, G1, and G2.

In general, composite $\mathrm{G} 2$ presents the best tribological properties in vacuum, the COF and wear rate of which are $0.14-0.25$ and $(0.12-4.78) \times 10^{-5} \mathrm{~mm}^{3} \cdot \mathrm{N}^{-1} \cdot \mathrm{m}^{-1}$ from 25 to $800{ }^{\circ} \mathrm{C}$. These values are significantly lower than those of most reported metals in vacuum (COF $>0.4$, wear rate: $10^{-4}-10^{-3} \mathrm{~mm}^{3} \cdot \mathrm{N}^{-1} \cdot \mathrm{m}^{-1}$ ) $[38,39]$.

\subsection{Worn surface morphologies}

The worn surfaces were also characterized via SEM to clarify the dominant wear mechanism (Figs. 7-9). Figure 7 presents the SEM images of the worn surfaces for composite G0.5 at temperatures from 25 to $800{ }^{\circ} \mathrm{C}$. It is clear that the worn surfaces are characteristic of a smooth layer and delamination at temperatures of 25,400 , and $600{ }^{\circ} \mathrm{C}$, corresponding to the low wear rates. At 200 and $800{ }^{\circ} \mathrm{C}$, the main features include large grooves, delamination, and cracks, suggesting significant wear. These phenomena suggest that abrasive wear and delamination are the main wear mechanisms of composite G0.5 in vacuum.

Figure 8 illustrates the worn surfaces of composite G1 at various temperatures. The worn surface was smooth except for some obvious delamination and small flaking pits at 25 and $400{ }^{\circ} \mathrm{C}$. At $200{ }^{\circ} \mathrm{C}$, a smooth layer with small flaking pits appeared on the sliding surfaces. As the temperature increased to $600{ }^{\circ} \mathrm{C}$, the delamination disappeared and smooth layers appeared on the sliding surface, which are distinct from composite G0.5. At $800{ }^{\circ} \mathrm{C}$, composite G1 exhibited large grooves and strip-like delamination, similar to those of composite G0.5. These morphological changes of the worn surfaces conform with the wear rate variations. The main wear mechanism of 

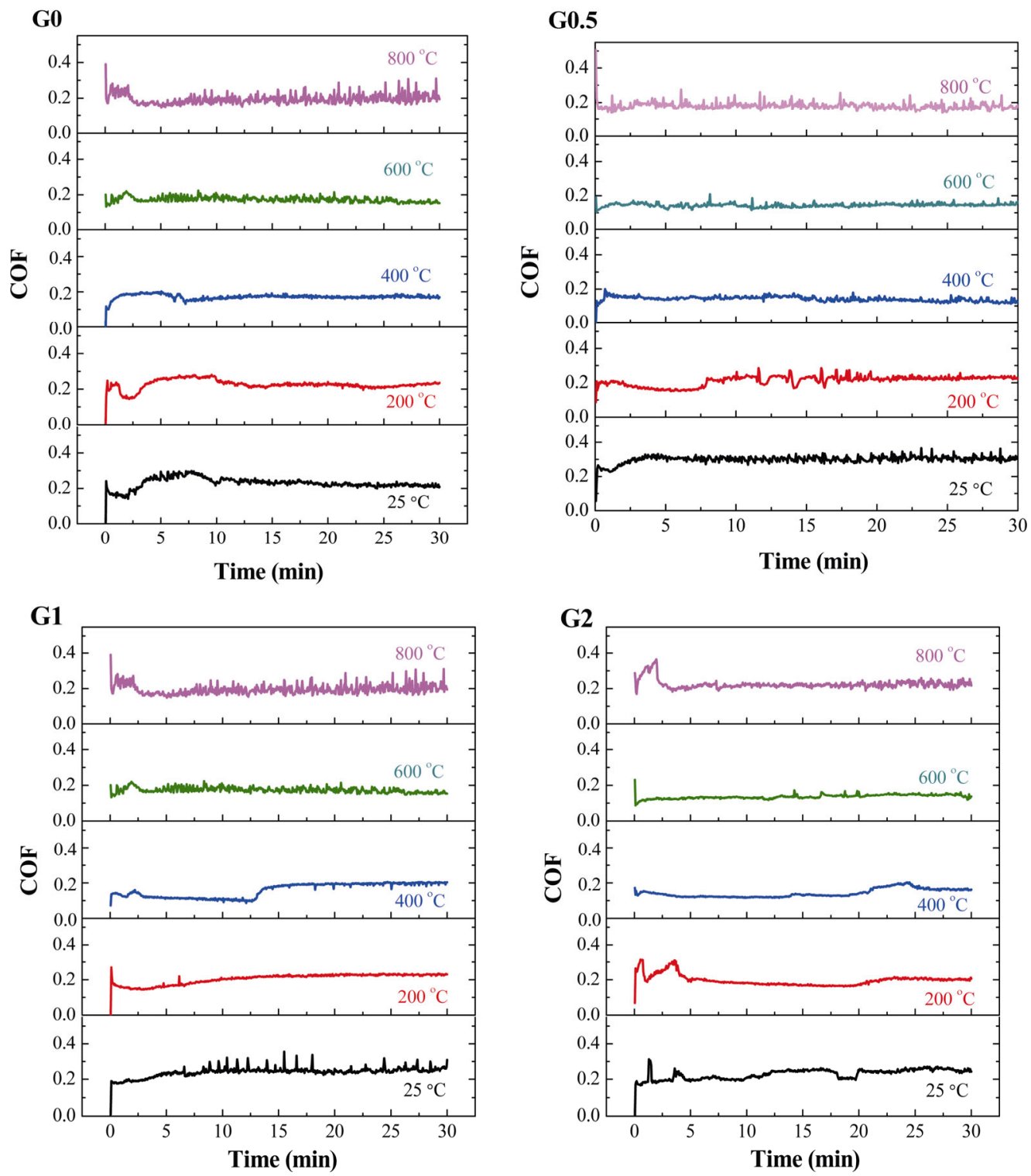

Fig. 5 Friction coefficients vs. sliding time curves for the composites at various temperatures in vacuum.

composite G1 also includes abrasive wear and delamination.

The typical SEM morphologies of the worn surfaces for composite $\mathrm{G} 2$ at various temperatures are exhibited in Fig. 9. At $25{ }^{\circ} \mathrm{C}$, composite $\mathrm{G} 2$ shows similar wear features compared with composite G1, characterized by a smooth layer except the delamination. However, from 200 to $800{ }^{\circ} \mathrm{C}$, a smooth tribolayer formed with the exception of some tiny grooves and small cracks on the worn surfaces, thereby resulting in the lowest wear rate within the temperature range of $200-800{ }^{\circ} \mathrm{C}$ in comparison to that of the other three composites. In short, abrasive wear is the main wear mechanism for composite G2 at temperatures of $200-800{ }^{\circ} \mathrm{C}$.

\subsection{Microhardness of the composites and worn surface compositions}

The microhardness values for the four composites from 25 to $800{ }^{\circ} \mathrm{C}$ are shown in Fig. 10. Clearly, the hardness decreases as the testing temperature increases. Composite G0 exhibited the highest value from 200 to $600{ }^{\circ} \mathrm{C}$, while $\mathrm{G} 2$ exhibited the lowest microhardness for all testing temperatures $\left(25-800{ }^{\circ} \mathrm{C}\right)$, and composites G0.5 and G1 presented similar values at 200, 400, and $800{ }^{\circ} \mathrm{C}$.

The compositions of the sliding surfaces at different 


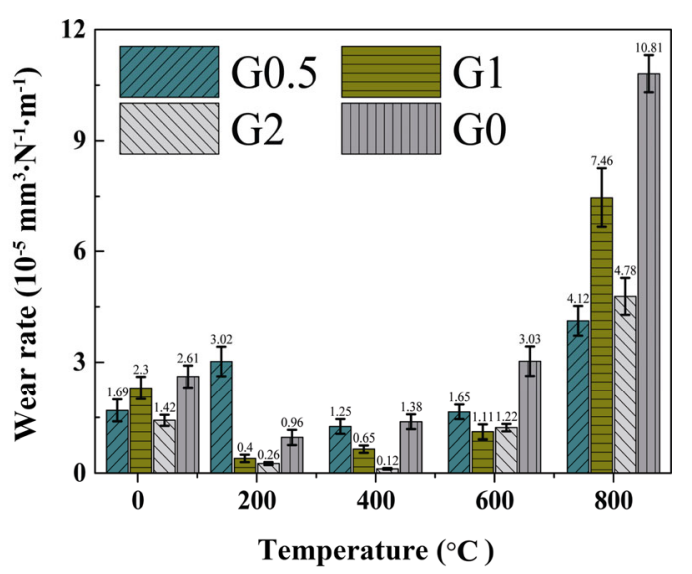

Fig. 6 Wear rates of nickel-alloy based composites as a function of testing temperatures.

temperatures were examined by EDS and Raman spectroscopy, as shown in Figs. 11 and 12. At temperatures of $25-600{ }^{\circ} \mathrm{C}$, the EDS observation of composite G2 (Fig. 11) indicates that the soft metal $\mathrm{Ag}$ is easily diffused, and smears onto the sliding surfaces to effectively form a lubricating film. Thus, the low $\mathrm{COF}$ and wear rate are obtained within the temperature range of $25-600{ }^{\circ} \mathrm{C}$. The Raman spectra of the contact surfaces for composite G2 at $400-800{ }^{\circ} \mathrm{C}$ are presented in Fig. 12 . At $400{ }^{\circ} \mathrm{C}$, almost no oxide could be seen on the worn surface. As the sliding temperature increased to 600 and $800{ }^{\circ} \mathrm{C}, \mathrm{NiCr}_{2} \mathrm{O}_{4}$ appeared on the worn surfaces, and its peak intensity increased from 400 to $800{ }^{\circ} \mathrm{C}$.

\subsection{Friction and wear mechanisms}

In our previous work [40], it was found that at temperatures from 25 to $400{ }^{\circ} \mathrm{C}$ in air, slight oxidation decreased the strength and thus increased the wear rate. While at temperatures of 600 and $800{ }^{\circ} \mathrm{C}$, the wear resistance is quite dependent on the oxidation rate, as the oxide glazed layer protects the composite from severe wear.

In vacuum, however, the friction and wear behaviors of the composites are quite different, which can be explained by the following, as shown in Fig. 13. First, from 25 to $400{ }^{\circ} \mathrm{C}$, the Raman results (Fig. 12) indicate that the tribo-oxidation on the worn surfaces is vastly suppressed compared with that in air. Second, the soft metal Ag is easily diffused to smear across the contact surface between friction pairs during the sliding process (Fig. 11); as the surrounding temperature increases, the diffusion rate of $\mathrm{Ag}$ increases, and the thickness of the lubricating films increase. Third, the transition from the brittle to ductile phase of fluorides is initiated at around $400-500{ }^{\circ} \mathrm{C}$, indicating that there will be a partial transition at $25{ }^{\circ} \mathrm{C}$ due to friction, which can increase the resistance and thus raise the COF. Meanwhile, increasing the temperature will soften the fluorides and reduce the transition. Therefore, the COF and wear rate decrease from 25
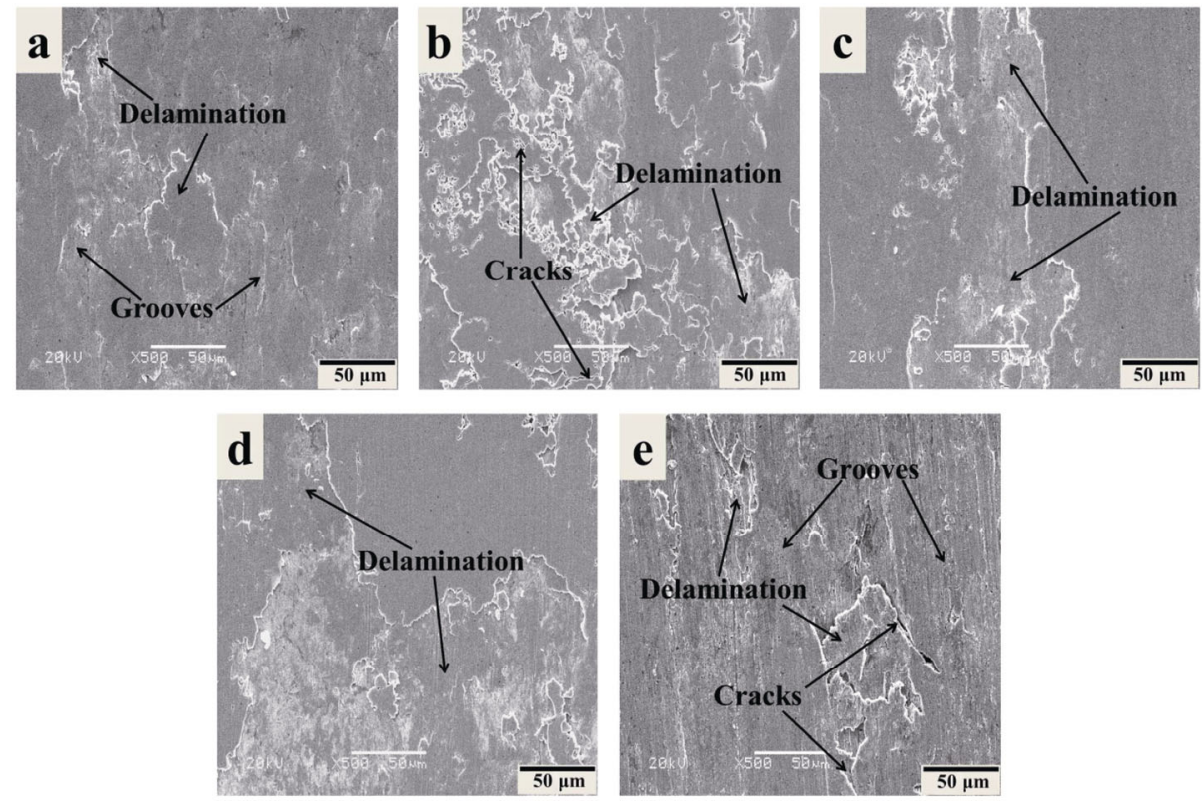

Fig. 7 SEM images of the worn surfaces of composite G0.5: (a) $25^{\circ} \mathrm{C}$, (b) $200{ }^{\circ} \mathrm{C}$, (c) $400{ }^{\circ} \mathrm{C}$, (d) $600{ }^{\circ} \mathrm{C}$, and (e) $800{ }^{\circ} \mathrm{C}$. 

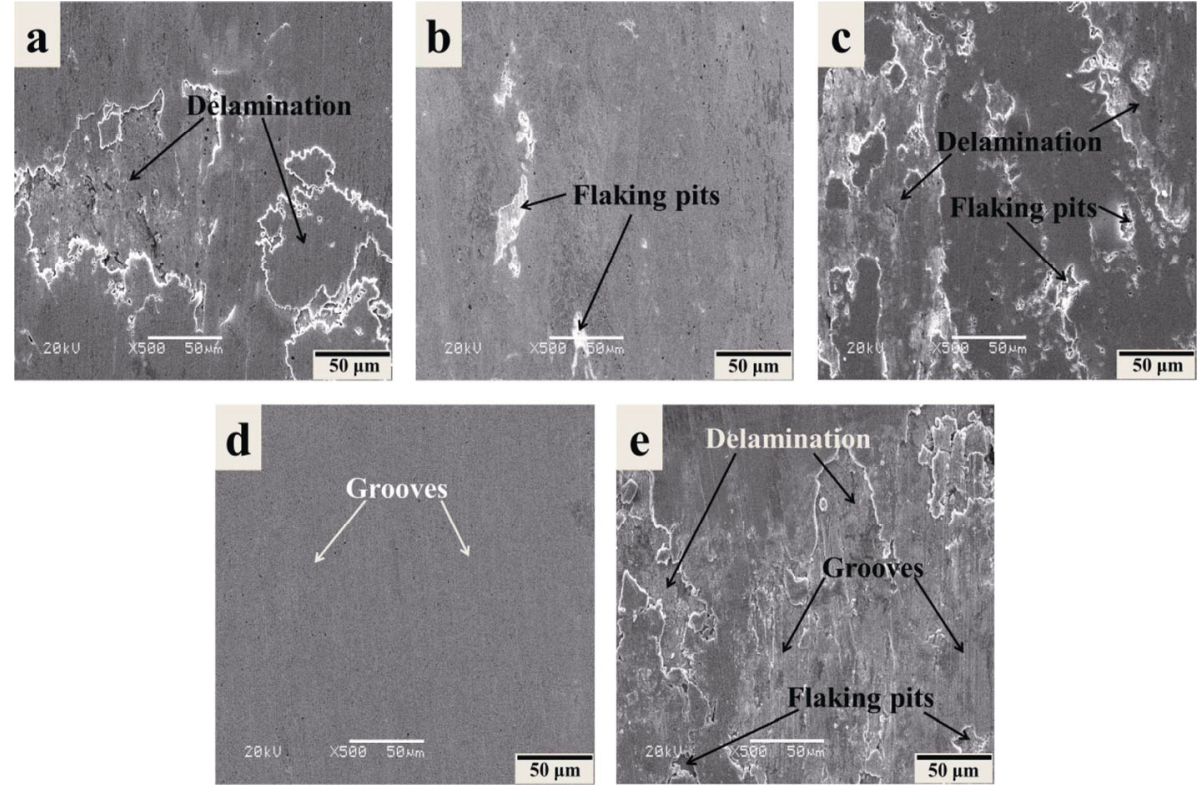

Fig. 8 SEM images of the worn surface of composite G1: (a) $25^{\circ} \mathrm{C}$, (b) $200{ }^{\circ} \mathrm{C}$, (c) $400{ }^{\circ} \mathrm{C}$, (d) $600{ }^{\circ} \mathrm{C}$, and (e) $800{ }^{\circ} \mathrm{C}$.
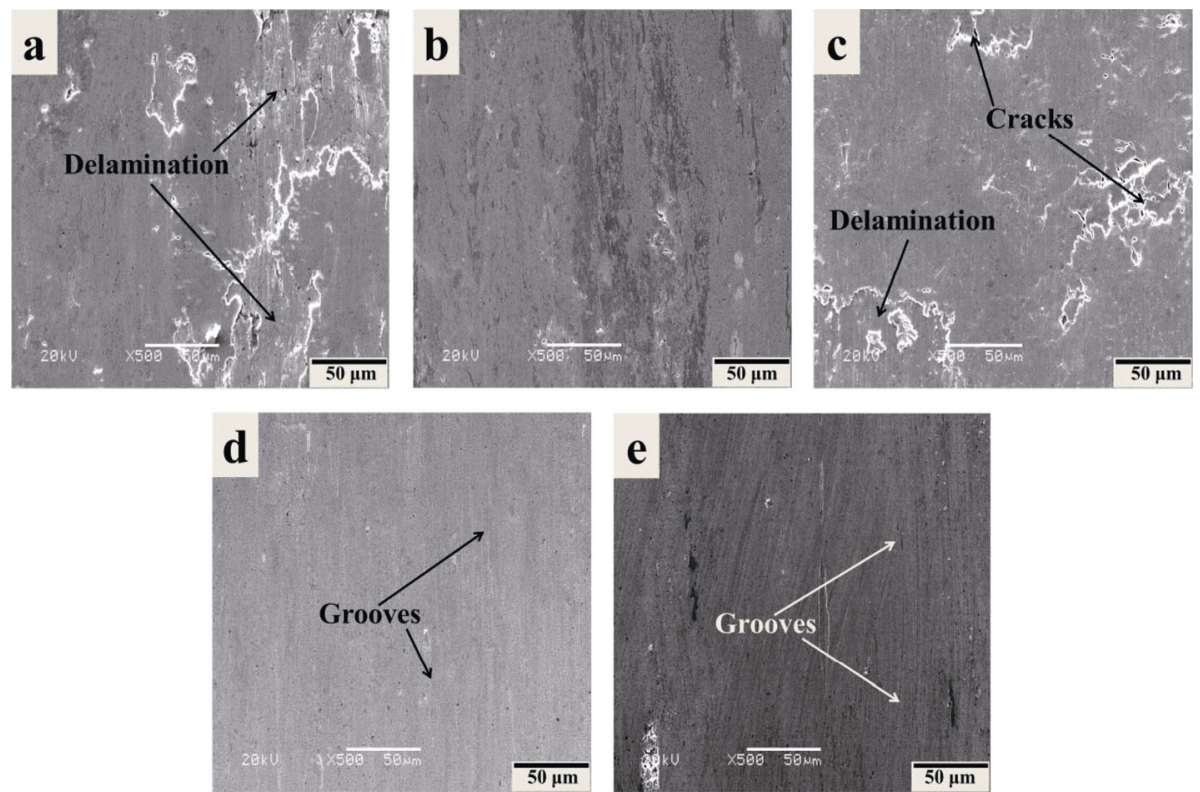

Fig. 9 SEM images of the worn surfaces of composite G2: (a) $25^{\circ} \mathrm{C}$, (b) $200{ }^{\circ} \mathrm{C}$, (c) $400{ }^{\circ} \mathrm{C}$, (d) $600{ }^{\circ} \mathrm{C}$, and (e) $800{ }^{\circ} \mathrm{C}$.

to $400{ }^{\circ} \mathrm{C}$ (Figs. 4 and 6). Furthermore, the lubricating and wear resistance properties of G2 are superior to those of G0, G0.5, and G1, particularly at 200 and $400{ }^{\circ} \mathrm{C}$. This results from the increasing content of high-strength carbide particles (formed in-situ during the hot pressing process) with the increase of the graphite content.

At $600{ }^{\circ} \mathrm{C}$, the soft $\mathrm{Ag}$ also smeared across the worn surfaces and synergized with the fluoride eutectic, thereby leading to the lowest COF. With further increasing of the temperature to $800{ }^{\circ} \mathrm{C}$, a small Ag film appeared on the sliding surface containing fluorides and $\mathrm{NiCr}_{2} \mathrm{O}_{4}$. On the one hand, the oxide layer decreases the diffusion rate of the solid-lubricant (mainly Ag) from the matrix to the worn surface; on the other hand, the oxide layer formed on the sliding surface cannot provide effective lubrication, so the lubricity decreases. Meanwhile, the decreased wear resistance of the composite at 600 and $800{ }^{\circ} \mathrm{C}$ is mainly due to the 


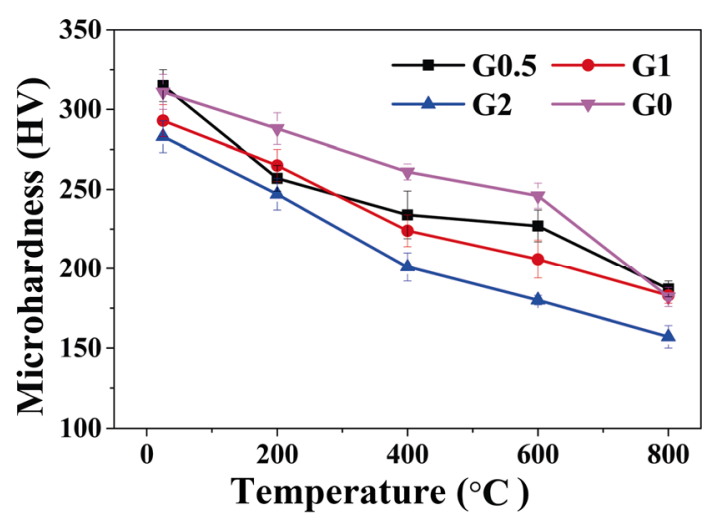

Fig. 10 Micro hardness of the nickel alloy matrix composites at different temperatures.

decreased hardness of the composites and slight oxidation of the worn surfaces (Figs. 10 and 12). Furthermore, the oxide layer that formed on the contact surface was too thin to resist the shearing force; thus, the most wear occurred at $800{ }^{\circ} \mathrm{C}$ (Fig. 6) and grooves appeared again on the worn surface (Figs. 7-9).

For comparison, composites G0.5, G1, and G2 exhibited similar COFs and wear rates at $600{ }^{\circ} \mathrm{C}$, with G1 presenting the highest value at $800{ }^{\circ} \mathrm{C}$ (Figs. 5 and 6). As can be found from Figs. 7-9, at $600{ }^{\circ} \mathrm{C}$, composites G0.5, G1, and G2 present smooth contact surfaces and steady friction curves, which may be due to the lubricious soft Ag film that formed on the worn surface, as proven by the EDS results (Fig. 11). At $800{ }^{\circ} \mathrm{C}$, the sliding surface for composite G2 was more easily oxidized due to the higher graphite content compared with those of composites G0.5 and G1, and the oxide layer can resist the shearing action of $\mathrm{Si}_{3} \mathrm{~N}_{4}$ ceramic ball; thus, a smooth worn surface is presented.

\section{Conclusions}

Ni-alloy matrix composites of $\mathrm{Ni}$-alloy/Ag/(Ca, $\mathrm{Ba}) \mathrm{F}_{2} /$ graphite were fabricated using hot pressing, and their vacuum tribological behaviors were systematically investigated. The main conclusions are as follows:

1) The composites exhibit excellent vacuum tribological properties at temperatures from 25 to $800{ }^{\circ} \mathrm{C}$; specifically, the COFs and wear rates are approximately $0.13-0.25$ and $(0.12-7.46) \times 10^{-5} \mathrm{~mm}^{3} \cdot \mathrm{N}^{-1} \cdot \mathrm{m}^{-1}$, respectively.
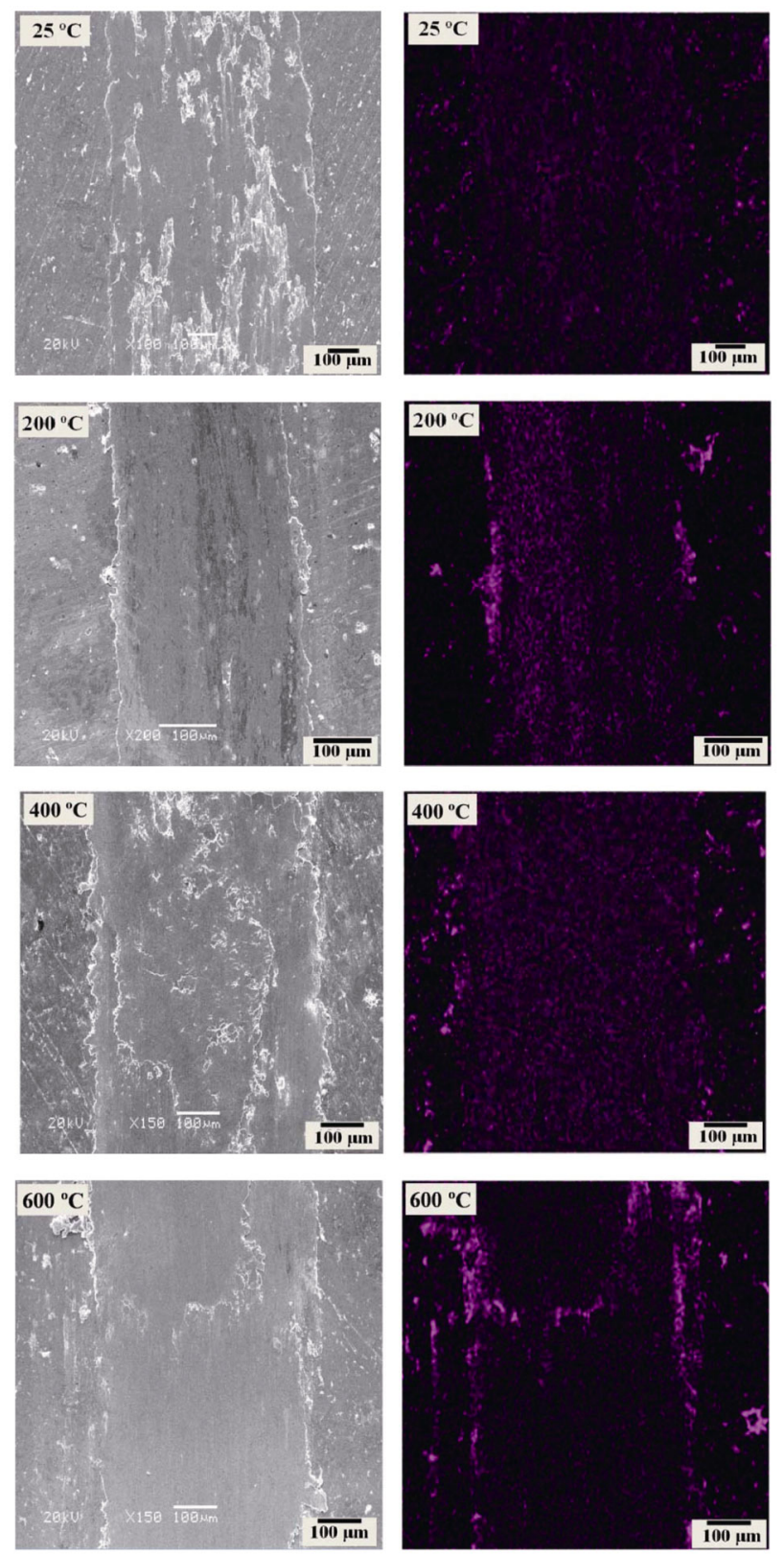

Fig. 11 SEM images of the worn surfaces of composite G2 and corresponding Ag element distribution maps from RT to $600{ }^{\circ} \mathrm{C}$.

2) The graphite content exerts a significant influence on the friction behavior of composites, and its optimal content is $2 \mathrm{wt} \%$. This may be because a high content of graphite forms more high-strength carbides during hot pressing, improving the tribological performance within the temperature range of $25-400{ }^{\circ} \mathrm{C}$. The worn surface of a composite with a higher content of graphite is readily oxidized, resulting in formation of a tribolayer and resistance to wear at 600 and $800{ }^{\circ} \mathrm{C}$.

3) In vacuum, the tribological performances of 

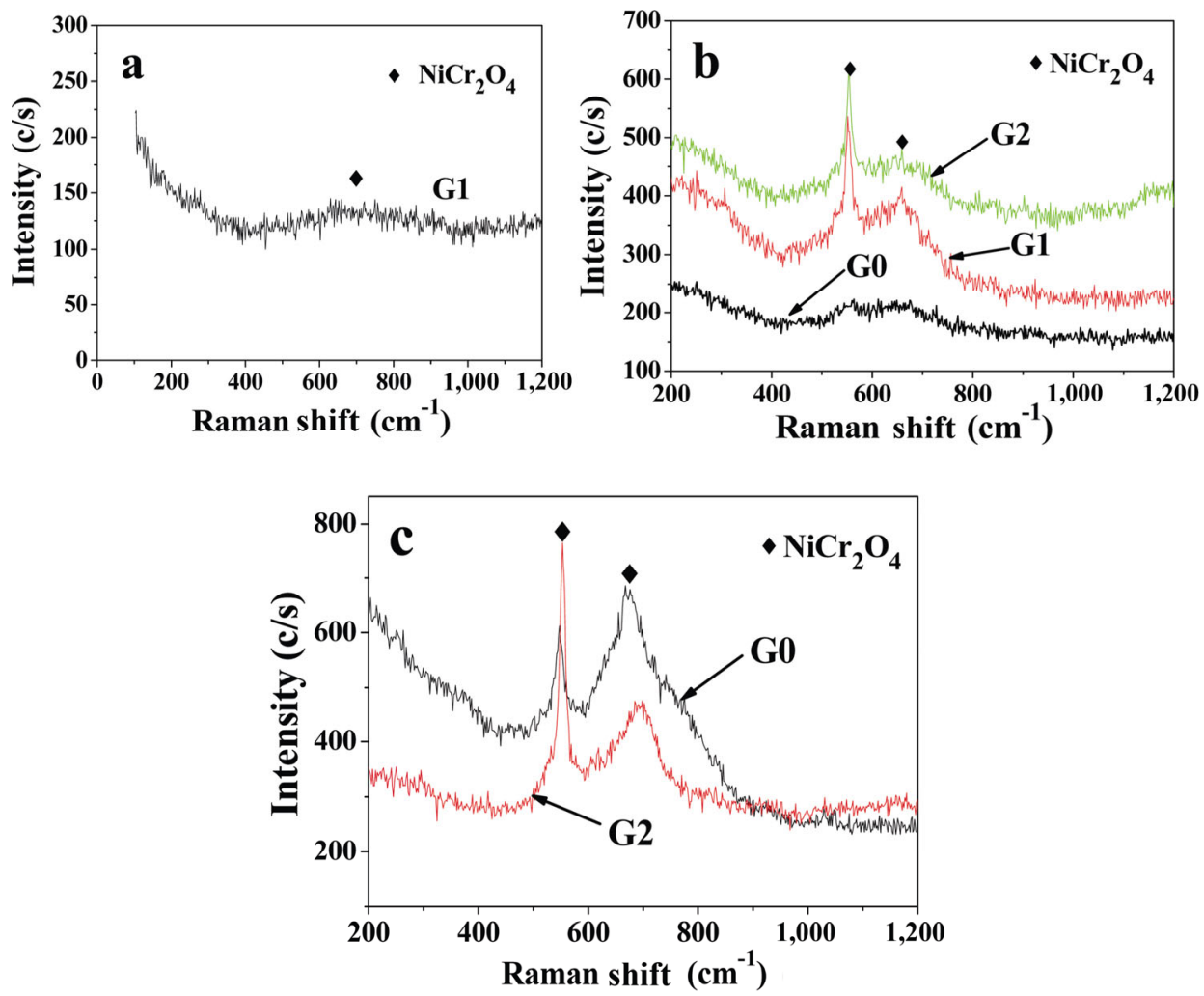

Fig. 12 Raman spectra of the worn surfaces for nickel-alloy matrix composite at different temperatures: (a) $400^{\circ} \mathrm{C}$, (b) $600{ }^{\circ} \mathrm{C}$, and (c) $800{ }^{\circ} \mathrm{C}$.

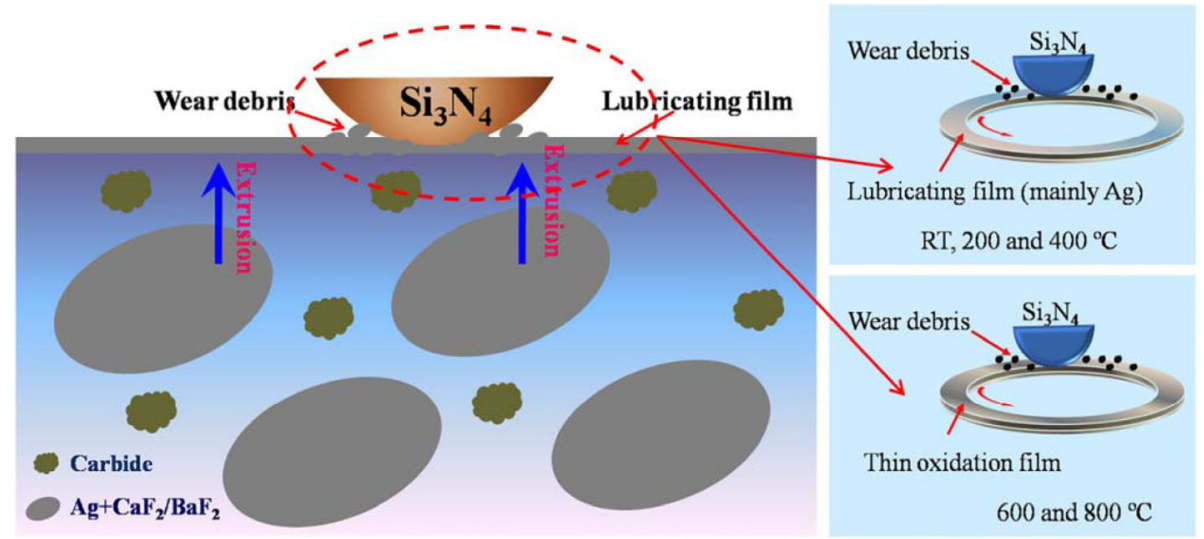

Fig. 13 Wear mechanism for composite at different temperatures.

the composites are superior below $600{ }^{\circ} \mathrm{C}$ compared with those above $600{ }^{\circ} \mathrm{C}$. Within the temperature range of $25-600{ }^{\circ} \mathrm{C}$, soft $\mathrm{Ag}$ diffuses onto the worn surface and forms a lubricating film, primarily contributing to the low $\mathrm{COF}$ and wear rate. At $800{ }^{\circ} \mathrm{C}$, although the oxide layer reduces wear, it prevents Ag from diffusing onto the sliding surface; thus, increases the COF.

4) The dominant wear mechanism of the composites in vacuum is abrasive wear.

\section{Acknowledgements}

This work was supported by the National Natural Science Foundation of China (Nos. 51675510 and 51975558) and the Open Foundation for the State Key Laboratory of Solid Lubrication (No. LSL1808).

Open Access: This article is licensed under a Creative Commons Attribution 4.0 International 
License, which permits use, sharing, adaptation, distribution and reproduction in any medium or format, as long as you give appropriate credit to the original author(s) and the source, provide a link to the Creative Commons licence, and indicate if changes were made.

The images or other third party material in this article are included in the article's Creative Commons licence, unless indicated otherwise in a credit line to the material. If material is not included in the article's Creative Commons licence and your intended use is not permitted by statutory regulation or exceeds the permitted use, you will need to obtain permission directly from the copyright holder.

To view a copy of this licence, visit http://creativecommons.org/licenses/by/4.0/.

\section{References}

[1] Muratore C, Voevodin A A. Chameleon coatings: Adaptive surfaces to reduce friction and wear in extreme environments. Annu Rev Mater Res 39: 297-324 (2009)

[2] Torres H, Ripoll M R, Prakash B. Tribological behaviour of self-lubricating materials at high temperatures. Int Mater Rev 63(5): 309-340 (2018)

[3] Zhu S Y, Cheng J, Qiao Z H, Yang J. High temperature solid-lubricating materials: A review. Tribol Int 133: 206-233 (2019)

[4] Prehn R, Haupert F, Friedrich K. Sliding wear performance of polymer composites under abrasive and water lubricated conditions for pump applications. Wear 259(1-6): 693-696 (2005)

[5] Rahman M S, Ding J, Beheshti A, Zhang X H, Polycarpou A A. Elevated temperature tribology of Ni alloys under helium environment for nuclear reactor applications. Tribol Int 123: 372-384 (2018)

[6] Zhao Y, Feng K, Yao C W, Nie P L, Huang J, Li Z G. Microstructure and tribological properties of laser cladded self-lubricating nickel-base composite coatings containing nano- $\mathrm{Cu}$ and h-BN solid lubricants. Surf Coat Technol 359: 485-494 (2019)

[7] Liu X B, Liu H Q, Liu Y F, He X M, Sun C F, Wang M D, Yang H B, Qi L H. Effects of temperature and normal load on tribological behavior of nickel-based high temperature self-lubricating wear-resistant composite coating. Compos Part B: Eng 53: 347-354 (2013)

[8] Rahman N U, Matthews D T A, de Rooij M, Khorasani A M, Gibson I, Cordova L, Römer G W. An overview: Laser-based additive manufacturing for high temperature tribology. Front Mech Eng 5: 16 (2019)
[9] Sharma S M, Anand A. Solid lubrication in iron based materials-a review. Tribol Ind 38(3): 318-331 (2016)

[10] Nian J Y, Chen L W, Guo Z G, Liu W M. Computational investigation of the lubrication behaviors of dioxides and disulfides of molybdenum and tungsten in vacuum. Friction 5(1): 23-31 (2017)

[11] Tudela I, Cobley A J, Zhang Y. Tribological performance of novel nickel-based composite coatings with lubricant particles. Friction 7(2): 169-180 (2018)

[12] Ul Haq M I, Anand A. Dry sliding friction and wear behaviour of hybrid AA7075/ $\mathrm{Si}_{3} \mathrm{~N}_{4} / \mathrm{Gr}$ self lubricating composites. Mater Res Express 5(6): 066544 (2018)

[13] Duan C J, He R, Li S, Shao M C, Yang R, Tao L M, Wang C, Yuan P, Wang T M, Wang Q H. Exploring the friction and wear behaviors of Ag-Mo hybrid modified thermosetting polyimide composites at high temperature. Friction 8(5): 893-904 (2020)

[14] Stanford M K, Yanke A M, DellaCorte C. Thermal effects on a low $\mathrm{Cr}$ modification of PS304 solid lubricant coating. NASA/TM-2003-213111 (2004)

[15] DellaCorte C, Edmonds B J. PS400: A new high temperature solid lubricant coating for high temperature wear applications. NASA-TM-2009-215678 (2009)

[16] Stone D, Liu J, Singh D P, Muratore C, Voevodin A A, Mishra S, Rebholz, Ge Q, Aouadi S M. Layered atomic structures of double oxides for low shear strength at high temperatures. Scr Mater 62(10): 735-738 (2010)

[17] Stone D S, Harbin S, Mohseni H, Mogonye J E, Scharf T W, Muratore C, Voevodin A A, Martini A, Aouadi S M. Lubricious silver tantalate films for extreme temperature applications. Surf Coat Technol 217: 140-146 (2013)

[18] Anand A, Sharma S M. High temperature friction and wear characteristics of $\mathrm{Fe}-\mathrm{Cu}-\mathrm{C}$ based self-lubricating material. Trans Indian Inst Metals 70(10): 2641-2650 (2017)

[19] Li F, Cheng J, Zhu S Y, Hao J Y, Yang J, Liu W M. Microstructure and mechanical properties of Ni-based high temperature solid-lubricating composites. Mater Sci Eng: A 682: 475-481 (2017)

[20] Sharma S M, Anand A. Friction and wear behaviour of Fe-Cu-C based self lubricating material with $\mathrm{CaF}_{2}$ as solid lubricant. Ind Lubr Tribol 69(5): 715-722 (2017)

[21] Zhen J M, Han Y X, Chen J, Cheng J, Zhu S Y, Yang J, Kong L Q. Influence of Mo and Al elements on the vacuum high temperature tribological behavior of high strength nickel alloy matrix composites. Tribol Int 131: 702-709 (2019)

[22] Zhu S Y, Li F, Ma J Q, Cheng J, Yin B, Yang J, Qiao Z H, Liu W M. Tribological properties of $\mathrm{Ni}_{3} \mathrm{Al}$ matrix composites with addition of silver and barium salt. Tribol Int 84: 118-123 (2015)

[23] Zhang X H, Cheng J, Niu M Y, Tan H, Liu W M, Yang J. Microstructure and high temperature tribological 
behavior of $\mathrm{Fe}_{3} \mathrm{Al}-\mathrm{Ba}_{0.25} \mathrm{Sr}_{0.75} \mathrm{SO}_{4}$ self-lubricating composites. Tribol Int 101: 81-87 (2016)

[24] Li B, Jia J H, Gao Y M, Han M M, Wang W Z. Microstructural and tribological characterization of NiAl matrix self-lubricating composite coatings by atmospheric plasma spraying. Tribol Int 109: 563-570 (2017)

[25] Xu C H, Wu G Y, Xiao G C, Fang B. $\mathrm{Al}_{2} \mathrm{O}_{3} /(\mathrm{W}, \mathrm{Ti}) \mathrm{C} /$ $\mathrm{CaF}_{2}$ multi-component graded self-lubricating ceramic cutting tool material. Int $J$ Refract Metals Hard Mater 45: 125-129 (2014)

[26] Li F, Zhu S Y, Cheng J, Qiao Z H, Yang J. Tribological properties of Mo and $\mathrm{CaF}_{2}$ added $\mathrm{SiC}$ matrix composites at elevated temperatures. Tribol Int 111: 46-51 (2017)

[27] Zhen J M, Cheng J, Zhu S Y, Hao J Y, Qiao Z H, Yang J, Liu W M. High-temperature tribological behavior of a nickel alloy matrix solid-lubricating composite under vacuum. Tribol Int 110: 52-56 (2017)

[28] Ando Y, Abe S. Friction and wear properties of nanostripe-inducing structures in vacuum environment. Wear 424-425: 62-69 (2019)

[29] Voevodin A A, Phelps A W, Zabinski J S, Donley M S. Friction induced phase transformation of pulsed laser deposited diamond-like carbon. Diam Relat Mater 5(11): 1264-1269 (1996)

[30] Du S M, Li Z, He Z T, Ding H L, Wang X C, Zhang Y Z. Effect of temperature on the friction and wear behavior of electroless Ni-P-MoS $-\mathrm{CaF}_{2}$ self-lubricating composite coatings. Tribol Int 128: 197-203 (2018)

[31] Torres H, Vuchkov T, Slawik S, Gachot C, Prakash B, Ripoll M R. Self-lubricating laser claddings for reducing friction and wear from room temperature to $600{ }^{\circ} \mathrm{C}$. Wear 408-409: 22-33 (2018)

[32] Zhen J M, Zhu S Y, Cheng J, Li M H, Lu Y, Qiao Z H, Yang J. Influence of graphite content on the dry sliding

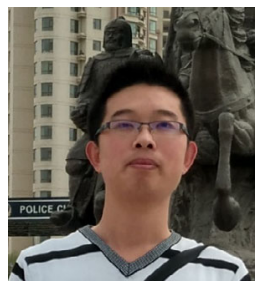

Jinming ZHEN. He received his M.S. and Ph.D. degrees in State Key laboratory of Solid Lubrication from Lanzhou Institute of Chemical Physics in 2014 and 2017, respectively.

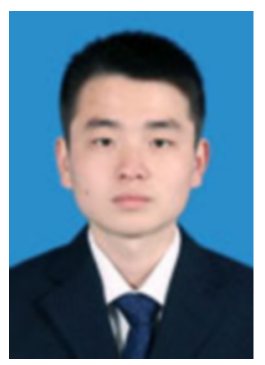

Jun CHENG. He received his Ph.D. degree in material science in 2014 from Lanzhou Institute of Chemical Physics, then he joined the State Key laboratory of Solid Lubrication at Lanzhou Institute of Chemical Physics. His current behavior of nickel alloy matrix solid lubricant composites. Tribol Int 114: 322-328 (2017)

[33] Torres H, Slawik S, Gachot C, Prakash B, Ripoll M. Microstructural design of self-lubricating laser claddings for use in high temperature sliding applications. Surf Coat Technol 337: 24-34 (2018)

[34] Jia Z F, Li H Q, Zhao Y, Frazer L, Qian B S, Borguet E, Ren F, Dikin D A. Electrical and mechanical properties of poly(dopamine)-modified copper/reduced graphene oxide composites. J Mater Sci 52(19): 11620-11629 (2017)

[35] Vohra K, Anand A, Ul H, Mir I, Raina A, Wani M F. Tribological characterization of a self lubricating PTFE under lubricated conditions. Mater Focus 5(3): 293-295 (2016)

[36] Ul Haq M I, Anand A. Friction and wear behavior of AA7075- $\mathrm{Si}_{3} \mathrm{~N}_{4}$ composites under dry conditions: Effect of sliding speed. Silicon 11(2): 1047-1053 (2019)

[37] Yin F L, Ji H, Nie S L. Tribological behavior of various ceramic materials sliding against CF/PTFE/graphite-filled PEEK under seawater lubrication. Proc Inst Mech Eng, Part J: J Eng Tribol 233(11): 1729-1742 (2019)

[38] Fu L C, Tan P, Zhu J J, Yang W L, Li D Y, Zhou L P. Tribological properties of surface nanocrystalline martensite steel in vacuum. Tribol Int 109: 246-251 (2017)

[39] Zhong H, Dai L Y, Yue Y, Zhang B, Feng Z H, Zhang X Y, Ma M Z, Khosla T, Xiao J, Liu R P. Friction and wear behavior of annealed Ti-20Zr-6.5Al-4V alloy sliding against 440C steel in vacuum. Tribol Int 109: 571-577 (2017)

[40] Zhen J M, Zhu S Y, Cheng J, Qiao Z H, Liu W M, Yang J. Effects of sliding speed and testing temperature on the tribological behavior of a nickel-alloy based solidlubricating composite. Wear 368-369: 45-52 (2016)

Presently, he is a lecture of College of Materials Science and Engineering at Liaocheng University. His primary research interests are surface coating, high temperature tribology, and surface characterization.

position is an associate professor. His research is mainly focused on high temperature tribology, liquidmetal tribology, and the design and application of frictional materials. 


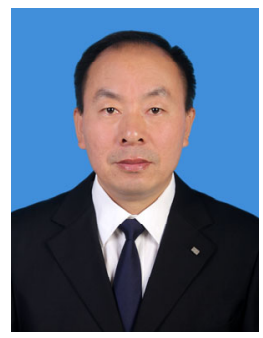

Jun YANG. He received his Ph.D.

Physics. His current position is a full professor degree in material science and engineering in 2005 from Lanzhou Institute of Chemical Physics. Then, he joined the State Key laboratory of Solid Lubrication at and the deputy director of the laboratory. His major research interests are high-temperature tribology, tribology of nanomaterials, combustion synthesis of nanostructured materials, and powder metallurgical materials. 